
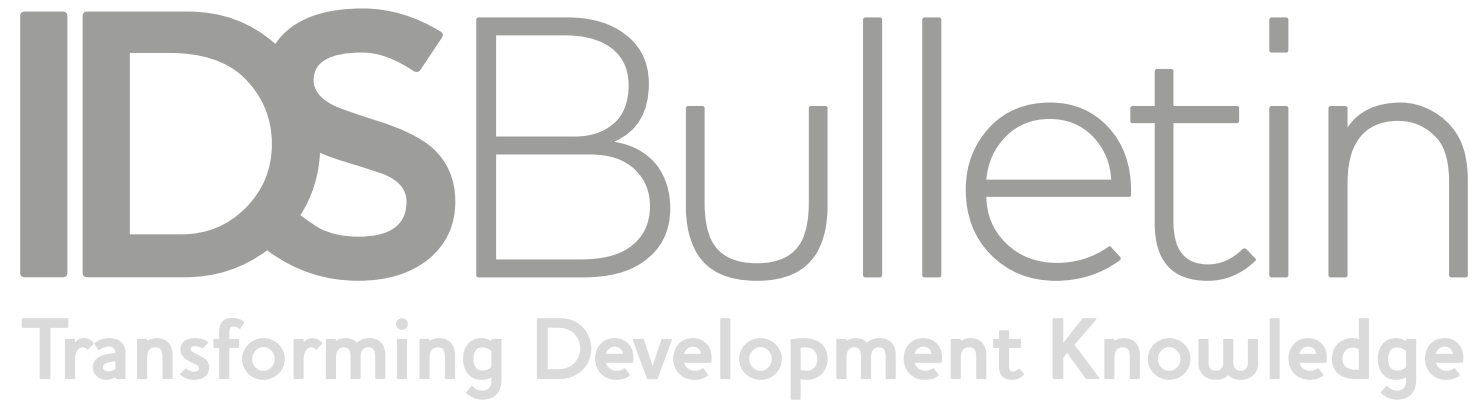

Development Knowledge

Volume 50 | Number 4 | December 2019

\title{
THE BELT AND ROAD INITIATIVE AND THE SDGs: TOWARDS EQUITABLE, SUSTAINABLE DEVELOPMENT
}

\section{Editors Gong Sen, Melissa Leach and Jing Gu}

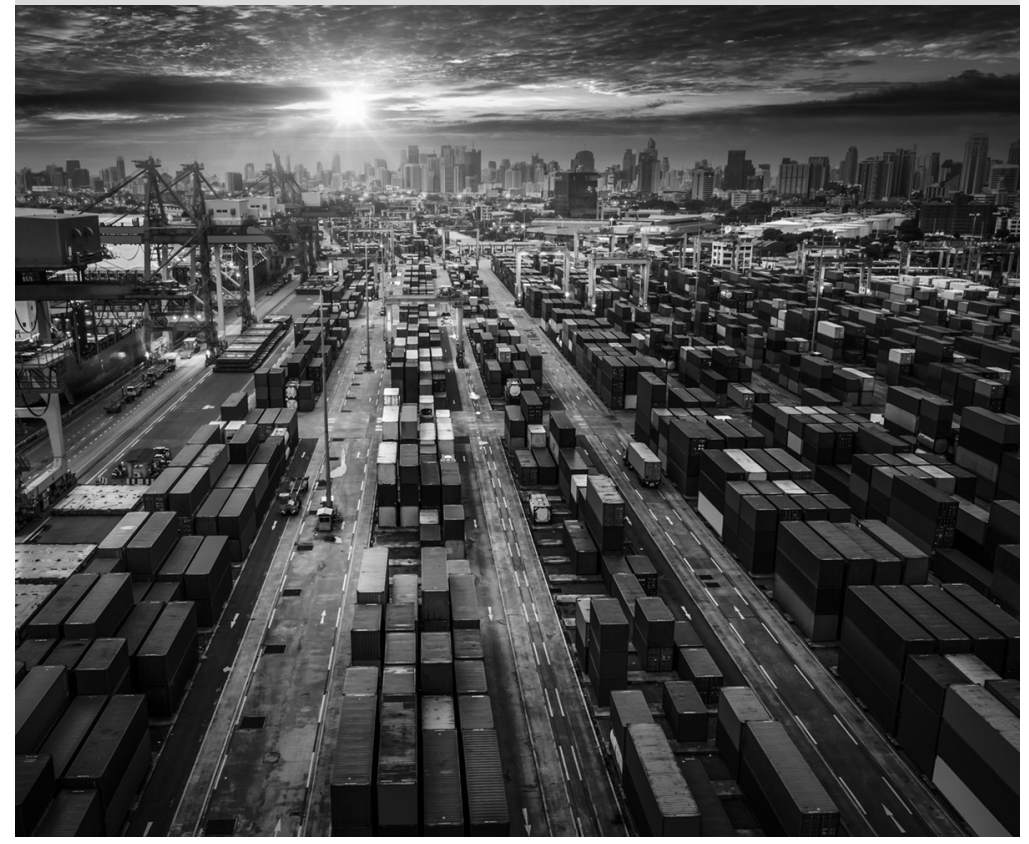


Notes on Contributors

Introduction: The Belt and Road Initiative and the Sustainable Development Goals: Opportunities and Challenges

Jing Gu, Hannah Corbett and Melissa Leach

\section{The Digital Silk Road and the Sustainable Development Goals}

Gong Sen and Li Bingqin

Green Belt and Road Initiative Environmental and Social Standards: Will Chinese Companies Conform?

Jiang Xiheng

Aligning the Belt and Road Initiative with Myanmar's Sustainable Development Plan: Opportunities and Challenges

Zhou Taidong

The Belt and Road Initiative and Africa's Sustainable Development: A Case Study of Kenya

Jing Gu and Shen Qiu

Sino-Greek Economic Cooperation: COSCO's Investment in the Port of Piraeus Liv Qianqian and Polyxeni Davarinou

The China-Pakistan Economic Corridor: A Case Study

Mustafa Hyder Sayed

Will the Belt and Road Initiative Boost Least Developed Countries Towards Sustainable Development?

Namsuk Kim

Glossary 


\title{
The Digital Silk Road and the Sustainable Development Goals*
}

\author{
Gong Sen ${ }^{1}$ and Li Bingqin ${ }^{2}$
}

\begin{abstract}
The information and communications technology (ICT) sector has attracted growing interest among stakeholders in countries involved in the Belt and Road Initiative (BRI) and Chinese investors. A Digital Silk Road initiative within the BRI is growing, as countries are encouraged to work together on production and trade enabled by digital technologies. Digital connectivity and the emerging digital economy can have positive impacts on development, as has been demonstrated in some Chinese cities. However, it is difficult to tell whether the Chinese experience will be transferable. This article reviews what China has done in relation to the Digital Silk Road and the possible contributions made towards delivering the Sustainable Development Goals (SDGs) in investee countries. We conclude that while ICT investment has the transformative power to benefit the world's poorest, its benefits should not be overestimated. Enhancing activities in the virtual world need to be matched with those in the real world to deliver sustainable outcomes.
\end{abstract}

Keywords: Digital Silk Road, Sustainable Development Goals, ICT infrastructure, digital, technology, Belt and Road Initiative, barriers to development, China, multilateral relations, digital information.

\section{Introduction}

The Belt and Road Initiative (BRI) was proposed to develop economic cooperation between countries along the Silk Road. As the countries involved are often poor countries which are not very active in industrial production and international trade, building economic infrastructure, such as Special Economic Zones and transportation infrastructure, has become essential for enhancing economic connectivity and facilitating trade. Between 2013 and 2018, the largest proportion of investment was in physical infrastructure such as ports and railway lines. The total investment by China in BRI countries has reached US\$90bn, with an average growth of 5.2 per cent annually, while BRI countries in kind have invested over US\$40bn in China (Renwick forthcoming, 2019). 
The content of the BRI is evolving. As information and communications technology (ICT) allows the digital economy to thrive in the digital age, China has started to harvest the benefits of the fast-growing and innovative digital economy domestically. The ground-breaking force lies in the ability of the digital economy to empower disadvantaged regions and the population, in a way which would have been impossible in the past. Digital trading platforms or social networks such as Taobao, JD.com, and WeChat have transformed the way enterprises operate and have brought new opportunities and innovations. This has had a notable positive impact on some of the most impoverished communities, which had previously been trapped in poverty through geographic isolation ( $\mathrm{Li}$ et al. 2018), and the disabled (Goggin et al. 2019; Zhong 2018).

The digital economy and the businesses that operate within it have become a powerful driving force behind China's rural poverty reduction (He 2019). At the 2015 Hangzhou G20 Summit, following a speech by China's president, Xi Jinping, the G20 members agreed that the digital economy could have great potential in delivering development outcomes. The aspiration was that there could be synergies among the BRI countries, particularly between the digitalisation of the Silk Road and the Sustainable Development Goals (SDGs) (Cyberspace Administration of China 2016). During the 2016 World Internet Summit, nine countries put in motion an initiative to develop cooperation in the field of the digital economy amongst countries along the Digital Silk Road. In May 2017, Xi Jinping spoke at the opening ceremony of the Belt and Road International Cooperation Forum:

We will continue to drive innovation, strengthen cooperation in cutting-edge areas such as the digital economy, artificial intelligence, nanotechnology, and quantum computing, and promote the construction of big data, cloud computing, and smart cities to connect to the 21st century Digital Silk Road (Xinhua News 2017).

To this day, ICT-enabled economic cooperation and the application of other new technologies in the BRI countries has been called the Digital Silk Road.

The BRI has now been integrated into the United Nations (UN) 2030 Agenda for Sustainable Development (2030 Agenda) to achieve the SDGs (Renwick, Gu and Gong 2018). Further to this, UN agencies have urged China to bring the BRI in line with the 2030 Agenda. As the Secretary-General António Guterres stated at the opening of the Belt and Road Forum for International Cooperation:

While the Belt and Road Initiative and the 2030 Agenda are different in their nature and scope, both have sustainable development as the overarching objective. Both strive to create opportunities, global public goods and win-win cooperation. Both aim to deepen 'connectivity' across countries and regions: connectivity in 
infrastructure, trade, finance, policies and, perhaps most important of all, among peoples (Guterres 2017).

The World Bank also engages actively with the BRI through (1) convening, (2) analytical and advisory services, (3) project origination and preparation, (4) project financing, and (5) implementation support (World Bank 2018). As argued by some Chinese authors (see, for example, Cao 2016; Jin 2018), alignment between these two development agendas could serve as an external push, for Chinese enterprises that wish to operate internationally, to adopt better social standards and at the same time to contribute to the SDGs. Xue and Weng (2018) also showed how incorporating individual BRI projects into a host country's framework for SDG implementation could benefit the implementation of BRI projects within host countries.

In principle, as a new component of the BRI, the Digital Silk Road should also work in line with the 2030 Agenda. However, little research has been done to examine whether the Digital Silk Road is able to contribute to the 2030 Agenda and what the advantages and limitations of e-commerce are as an instrument for delivering the SDGs. This article is an attempt to fill in this identified gap in the literature. There are multiple types of technologies included in the Digital Silk Road initiatives. This article focuses on digital technology.

\section{Barriers to sustainable development and digital solutions 2.1 Barriers to sustainable development}

An important strand of the development studies literature focuses upon the barriers to development. As this is the era of sustainable development, it is also important to identify the barriers towards achieving the SDGs. As countries are in the middle of implementing the SDGs, barriers to their achievement may yet be exposed. The focus of recent literature on the barriers to realising the SDGs tends to be on various environmental factors. However, from the perspective of policy and implementation, the accumulated research outputs on the barriers to economic and human development and the most recent findings on environmental sustainability should all be taken into account to develop a balanced and comprehensive picture.

Earlier researchers identified multiple interlinked development traps: conflict; reliance on natural resources; being landlocked with bad neighbours; and bad governance (Collier 2007). Over time, the concept of human development replaced the focus on overall economic growth, with the former arguing for focusing on how people fare as the economy grows. For a human being to thrive and be part of society, they need multiple capitals (physical, financial, social, political, human) and infrastructure to support them to develop the capability to achieve what they want to achieve (Sen 2004). The most significant barriers to universal human development, as pointed out by Bonini (2017) are income, and social and political inequalities. He argues that the solutions are not limited to technology and funding. 
The SDGs are a combination of goals for human development and environmental sustainability. Under this newer framework, development is expected to be people-centred and planet-sensitive. The barriers to implementing the SDGs include multiple sources: (1) economic and financial barriers (Adhikari 2018); (2) barriers to innovations (Filho et al. 2017); (3) social barriers (population growth, paired with unsustainable consumption and production patterns among the wealthy); (4) political barriers (including political will and governing capacities) (Urmee and Md 2016); (5) poor monitoring and evaluation systems (Olsen et al. 2014); (6) institutional barriers (Shiel, Smith and Cantarello 2018); and (7) trade barriers (de Melo and Solleder 2018).

The authors agree that technology cannot be the only solution to achieving sustainable development. However, as the world economy has entered the digital age and digital technology has been transforming people's lives as well as redefining market boundaries and changing the ways businesses and people work so profoundly, it is important to examine what digital technology can achieve and what barriers exist that may prevent it from reaching its potential.

\subsection{Digital solutions and the barriers to development}

There is a growing body of literature on the potential of digital technologies (ICTs). ICT investment may have the potential to contribute to all perspectives of development and help to remove any barriers, one way or another.

1 ICT as a form of information infrastructure has offered connectivity like other physical infrastructure insomuch as it can link landlocked countries or poverty-ridden regions to the outside world $(\mathrm{Ng}$ and Tan 2018; Alexopoulos 2018).

2 Economic and political activity based on the ICT infrastructures have boosted trade and financial resources across borders (Mbise et al. 2018 on financial aid for trade) and have the potential to channel agency for the population whose voices may be less heard or whose needs are considered to be less of a priority than those of the established institutions (Maurer, Nelms and Rea 2018). Not having access to digital technology thus has the potential to directly affect the opportunities of some of the most impoverished populations in the world (Yu et al. 2018).

3 Digital platforms and business transactions may also generate social network effects (Murendo et al. 2018) and facilitate risk-sharing (Riley 2018), and thus generate unexpected social capital (Ahmed 2018).

4 Access to digital technology may help to improve access to social services such as education and health care (Hong et al. 2017; Thapa and Sein 2018).

5 Enhancing ICT may also serve to improve environmental sustainability by monitoring environmental threats and through 
the assessment of environmental protection programmes (Asongu, Le Roux and Biekpe 2018; Mcdonald et al. 2002).

In this sense, digital infrastructure and the economic and social ecology based on this infrastructure would have the potential to overcome some of the barriers that had turned out to be challenging to get around or even considered to be developmental traps. However, like all technologies, digital technology can be a double-edged sword. There is a growing concern over how digital technology has been used to misinform rather than to inform (Mills 2016; Ciampaglia 2017), and to isolate rather than bridge understanding between people with differing opinions (Agarwal, Animesh and Prasad 2009). Despite the capability of digital technology to empower the less powerful, it can also empower those in power disproportionately, and enlarge rather than narrow the gaps between the developed and less developed world (Ahlfeldt, Koutroumpis and Valletti 2014; Fang et al. 2018).

\section{What may the Digital Silk Road offer to the delivery of the SDGs?}

It is well established that access to physical infrastructure may help to initiate trade and open doors for people from the most impoverished regions to the outside world, even if it cannot solve all the problems associated with poverty. As part of the BRI, the Digital Silk Road is an add-on to the conventional physical infrastructure. By linking countries with fibre-optic cables, mobile structures, and e-commerce links, and introducing common technical standards in participating nations, the Digital Silk Road can function to complement or supplement physical infrastructure. As discussed earlier, digital networks may help businesses in poor countries to be better prepared; for example, gathering information about global events, especially in relation to target markets and creating efficient business links, and also through calls for charity donations. However, some countries involved in the BRI do not even have the basic ICT infrastructure to allow them to tap into the world market (James 2009) and ICT access can be disproportionate, with cities and the more affluent population having better access (Onitsuka et al. 2018).

Despite theoretical claims, there is little practical evidence that can give Chinese policymakers the needed support for the Digital Silk Road. This is due to the newness and rapid evolution of the Digital Silk Road initiative, along with the Chinese government's different approach to governance, i.e. domestic policy inspiration is often drawn from the international experiences of the elites (Houlihan, Tan and Green 2010) and introduced top down; sometimes it is first experimented with using pilots at the local level (Ngar-Yin Mah and Hills 2014).

Yet, what has given the Chinese government the confidence to go about promoting digital infrastructure abroad is its own domestic experience with recent inland regional development; for example, in the Chongqing-Sichuan-Guizhou and Ningxia-Qinghai-Gansu regions, which were some of the poorest provinces in China. These provinces found it hard to compete with coastal cities such as Shanghai and 
Guangzhou. They were geographically isolated, and investors found it hard to move their businesses to these regions. Despite these barriers, they represented abundant labour resources and much cheaper labour costs than the coastal regions. Still, it was not economical for exporters to operate in these cities because of the difficulties and cost to export the goods produced. As the coastal regions thrived with sustained growth, for years these southwest regions remained suppliers of cheap migrant labourers to the more prosperous regions.

Overall, it took them several steps to move out of the poverty trap:

1 At the turn of the century, with the help of the Developing the Western Regions initiative, these regions invested heavily in improving infrastructure. Thanks to a more convenient connection to the main railway network, road and aviation networks, and new economic development zones, as well as the early adoption of some of the best internet networks in China, these regions managed to attract investors from coastal regions and became the fastest growing regions in terms of gross domestic product (GDP) growth in China in the early 2010s (Katz and Jones 2015). The gap in GDP per capita at provincial level during 2009 and 2016 between the western provinces and the richest provinces had been narrowed, reversing a 30-year widening trend ( $\mathrm{Li} 2017$ ).

2 Since 2007, with the support of some of the most advanced digital infrastructure in China, these inland cities have been able to compete with the richest regions in China on high-tech and high-end financial services in a way that they would not have dreamt of in the past (Liu and Hu 2010; McNally 2004). Guizhou, which hosts some of the poorest counties in China, started to sell premium farm produce or horticultural products through e-commerce to the wealthiest cities in the country. The much cheaper and accessible internet financial services allowed smaller businesses to gain competitiveness in the market (Turvey and Xiong 2017). More recently, connectivity within these provinces has also given them the power to take advantage of their own large markets and let their customers enjoy the benefits of more accessible services and products (Tan et al. 2011; Leong et al. 2016). These new opportunities resulted in a surge of returning migrants and talents who became entrepreneurs or who were employed by the large companies that had settled in these regions, despite the benefits of large-city living (Mohabir, Jiang and Ma 2017; Bai, Wang and Zhang 2018).

Aside from the business sector, increasingly, digital infrastructure has also changed the way Chinese governance works. Community-based digital governance platforms and government digital complaint systems were set up to generate and channel people's voices upwards to help local governments to improve their performance (Chu, Yeh and Chuang 2008). The ability to respond to public complaints promptly has been built into the key performance indicators of the local officials concerned 
(Gao 2015; Almén 2018). It has been used widely in monitoring service and infrastructure accessibility and quality, and public and environmental health, as well as environmental governance (Zhang, Mol and He 2016; Li 2018).

Despite international criticism of a surveillance state potentially emerging, the broader use of digital networks has benefited the impoverished regions to deliver results in all perspectives of human development as well as sustainable development (Giroux 2014; Trojanow et al. 2015). Using online teaching or teacher training and remote health-care provision or remote health-care professional support, some of the most isolated regions are able to receive some basic services that were not available to people in the past. Despite these results, livelihoods are still far from ideal (Yang, Zhu and MacLeod 2018; Hwang et al. 2018) and emerging solutions to overcome some of the most challenging barriers to development come predominantly from continual innovation (Tu, Wang and $\mathrm{Wu} 2018$ ).

The Chinese government's aspiration to use digital connectivity to support development internationally via the BRI is, to a great extent, a result of having seen what it has and can achieve in China. As Xiang (2017) suggests, ICT is meant to help open the possibilities for economic development, narrow the digital divides in terms of accessibility and unequal quality among BRI countries, and at the same time provide good-value-for-money products and services for people. The data collection, transmission, and sharing among the BRI countries, or spatial information passageways, may provide supplementary information to monitor and evaluate the progress of participating countries along the Belt and Road (B\&R) on sustainable development (Gong, Gu and Teng 2019). The ability to do so, with the aid of China's experience, will be crucial for overcoming some of the barriers mentioned in Section 2.2; that is, to generate reliable monitoring, evaluation, and targets for delivering outcomes for the SDGs.

This is itself empowering or a form of capacity building for developing countries that do not necessarily have the same capacities as developed countries. The Chinese Academy of Sciences (2017) published the Report on Remote Sensing Monitoring of China Sustainable Development 2016, which argued that Chinese assistance in the development of a Digital Silk Road would lead to more open and just public administration. $\mathrm{Li}$ (2017) finds that enhanced internet coverage could make positive contributions to per capita GDP. The effect would be that ten more percentage points of coverage would increase GDP by 0.9 percentage points. Such findings are quite similar to those of Choi and Yi (2009) and Czernich et al. (2009) in different contexts.

\section{The Digital Silk Road: policy framework and associated cross- country collaboration}

In this section, we first outline the policy framework for the Digital Silk Road and the cross-country collaboration it has generated so far. 


\subsection{Intergovernmental collaboration}

By April 2019, China had signed collaborative agreements with 16 BRI partner countries to build up the Digital Silk Road together and has jointly signed a collaborative initiative for a B\&R Digital Economy with seven BRI countries. Some examples of these agreements signed by the Chinese Ministry of Industry and Information Technology within the BRI framework include:

A letter of intent with the International Telecommunication Union to strengthen cooperation within the ICT sector;

Bilateral Memoranda of Understanding (MoUs) with the government departments of Cambodia, Iran, Bangladesh, and Afghanistan;

Agreements with the five member states of the East African Community, Ethiopia, and the International Telecommunication Union to jointly build information highways in East Africa;

An action plan to strengthen a partnership for the joint development of ICTs between China and the Association of Southeast Asian Nations (ASEAN); and there has been significant progress in the construction of China-Myanmar, China-Pakistan, China-Kyrgyzstan, and China-Russia cross-border fibre-optic cables for information transmission (Office of the Leading Group for the BRI 2019).

\subsection{Multilateral relations}

By the end of 2017, China had 17 international terrestrial cable border stations with 12 neighbouring countries, and ten submarine optical cables had been laid to connect 12 countries (CAICT 2018). The Chinese government has been assisting three telecom enterprises to participate in the construction of a China-ASEAN Information Harbor (CAEXPO Secretariat 2018). Chinese industries have also been actively promoting the development of BeiDou-2, a Chinese global satellite navigation system, aiming to have 35 satellites by 2020. Several Asian countries, including Pakistan, Laos, Brunei, and Thailand, have adopted the system (Hao 2019).

\subsection{Chinese businesses and foreign governments}

Within the BRI framework, many private enterprises reached out to the national or local governments of the BRI countries to sign up collaboration agreements or to contract public infrastructure building. These activities have taken multiple forms:

Alibaba signed MoUs with the Pakistan Trade Development Bureau in May 2017 to promote the development of small- and mediumsized enterprises (SMEs) in Pakistan, and with the Thai government in April 2018. The latter would help to set up an intelligent data centre in the Eastern Economic Corridor (EEG) to help SMEs in the EEC to build a digital platform for tourism in Thailand and to enhance the capacity of local e-commerce workers. 
- Chinese companies have also been involved in the construction of smart cities in other countries. Both Huawei and Alibaba, for example, have engaged in the construction of Smart Dubai (Stewart 2019). Besides this, Alibaba Cloud Computing has been involved in the data analysis of the EZ-Link Card in Singapore (Asian Scientist Newroom 2017) and the digital transformation plan of Saudi Arabia (Viney, Pan and Fang 2017).

The Thai government has tried to attract Alibaba and Huawei to invest in the EEC. According to Rookie Network Technology Co. Ltd (Fu 2018), the critical Chinese network for smart logistics controlled by Alibaba has established a fast track for fresh agricultural products including Durio zibethinus murr. from Thailand to many major cities in China. Huawei established an open lab in Bangkok in June 2017, a collaborative and innovative platform for local customers and entrepreneurs. The total investment of the lab was US\$15m (Xinhua News 2017).

Some countries, such as Argentina, have embraced Alibaba's initiative of the Electronic World Trade Platform (eWTP) (Chu and Li 2018). In May 2017, the President of Argentina stated that the government had reached a strategic agreement with Alibaba regarding the eWTP.

\subsection{Direct investments and sales by Chinese businesses to BRI markets}

Chinese companies also increasingly invest or operate in foreign markets. For example, in 2016, the China Mobile Communications Corporation, China Unicom, and China Telecom invested about US\$800m in overseas markets and started business operations in many countries and regions including Pakistan, Thailand, and Singapore. These days, more app companies are becoming interested in international markets. As early as 2013, Huawei started to invest in Myanmar and donated equipment equivalent to US\$5m for various purposes, including to the Southeast Asian Games Organisation and for mobile technology systems (China News Agency 2017). Since 2018, the country's Ministry of Transport and Communications has been working with Huawei to develop $5 \mathrm{G}$ broadband services across Myanmar within the next five years. A further push was given to its $5 \mathrm{G}$ plans in February 2019 when Huawei pledged to increase digital literacy and the usage of the Internet of Things in Myanmar.

Chinese companies increasingly operate internationally in e-commerce, online to offline $(\mathrm{O} 2 \mathrm{O})$, social networking, utilities, content, and games. Apart from developed countries, Chinese apps are gaining users in BRI countries in Southeast Asia, South Asia, the Middle East, Latin America, and Africa. By the end of 2017, more than 700 companies had international businesses (iResearch 2018). 


\subsection{Chinese and foreign business partnerships}

Increasingly, international companies have started to join Chinese companies to work on BRI-related projects. For example, the Inspur Group initiated a B\&R Digital Economy Strategic Alliance in November 2017 together with Cisco, IBM, Diebold, and Ericsson (Inspur Group 2017). These companies developed a partnership with the Export-Import Bank of China, the China Development Bank, the China Export and Credit Insurance Corporation, and the ChinaAfrica Development Fund. The partnership was the first cooperative mechanism introduced by enterprises which would provide world-class data centres, as well as deliver cloud services and solutions to enable smart cities and smart enterprises.

The activities within the Digital Silk Road have shown that it is a gradually evolving field. The Chinese government has played a pivotal role in forming these initiatives; reaching agreements or mutual understandings with other countries' governments. It has also been actively encouraging Chinese enterprises that were not initially interested in developing business relationships abroad, particularly with developing countries. After the initial set-up and the availability of basic infrastructure, businesses from around the world started to engage, and an ecosystem started to develop around the initiatives.

\section{The Digital Silk Road and the Sustainable Development Goals}

Geopolitical debates and even confrontations have been taking place as the system continues to evolve. It is gaining importance in the BRI framework, and a lively ecosystem has emerged regardless. From the perspective of development, can this system deliver some of the desired outcomes relating to the SDGs?

\subsection{Leveraging digital connectivity to stimulate growth and reduce poverty and inequality}

As discussed in Section 2, for countries that have been trapped in poverty, digital connectivity provides new opportunities to accumulate human capital, tap into the international market, and improve social participation. However, access to digital infrastructure is only the starting point. The outcomes of digital enablement depend on the quality of connectivity, the supporting environment, and user capability. Therefore, it is not always realistic to expect digital connectivity to deliver development outcomes single-handedly. However, what can be expected is that improved digital connectivity (including improvement in accessibility and quality) can at least open up new opportunities. With growing investment and collaboration, the Digital Silk Road projects are developing fast in different directions in multiple developing countries (Gu and Carey 2019).

This article uses examples or cases published by Chinese official websites, academic research in Chinese and in English, as well as in media coverage of the BRI countries to put together the pieces of the jigsaw. 


\subsection{Enhancing connectivity}

Connectivity relating to the Digital Silk Road can be viewed from multiple perspectives. It can be through access to digital networks with devices. Oreglia (2019) reports that until 2014 or 2015, many small-town and rural business people did not have a phone and had to rely on travel agents, or go to wholesale markets, typically by bus on dangerous roads or by train on slow railway lines. Even in 2010, there were only 594,000 mobile phone subscribers in the country - 1.14 subscriptions per 100 inhabitants - and 493,314 landline subscribers -0.98 per 100 inhabitants. The cost of a SIM card was around US\$2,000 in the late 2000s, and still in the hundreds of dollars in the early 2010s. Private landlines were rare, especially outside major cities, so people used public phones, which were expensive and unreliable. Norwegian company Telenor and Qatari company Ooredoo helped to lower the price of SIM cards in cities instantly to US $\$ 1.50$, and mobile phone services became accessible to 89.8 per cent of the population in 2017, with 75.1 mobile broadband subscriptions per 100 inhabitants in 2017. In rural areas, Chinese budget models of Huawei, Honor and Oppo, for example, were more popular than the more expensive versions. Other 'local' brands also use phones made in China, and Chinese entrepreneurs manage the commercial distribution, marketing, and sales of the products. Other Chinese brands such as Coolpad, Gionee, Vivo, Meizu, and Zopo, typically unknown in the West, have been gaining significant market shares in emerging economies.

Connectivity can also mean the link between the Chinese market and BRI countries. Alibaba has been thriving by bringing companies into the digital world and trade. It has also helped foreign companies, particularly small and medium enterprises to tap into the vast Chinese domestic market (AliResearch 2019). On 31 October 2018, the first eWTP in Africa was launched in Kigali (Mugisha 2018), which has increased the sales of Rwandan coffee on Tmall (Gahigi 2019). The Taobao Village model was also introduced to Thailand to help tackle poverty and raise community income via e-commerce and digital technology (Arunmas 2018). In February 2019, the Eastern Economic Corridor Office of Thailand (EECO) established agreements with Alibaba to use e-commerce and digital technology to promote Thai products to Chinese customers (Eastern Economic Corridor 2019).

Connectivity may also mean access to business services. After successful innovation in China, Alipay has taken some share of financial technology (fintech) markets through mergers and acquisitions (M\&A) in India, Singapore, Korea, Russia, and Thailand. Such a cross-border exchange and accounting system were crucial for Alibaba's cross-border e-commerce cooperation. Paytm was the largest mobile payment and commerce platform in India but one year after being taken over by Ant Financial, it became the fourth biggest electronic wallet globally. By the end of 2017, Paytm had 215 million users, of which nearly 200 million were new users following the takeover (Sriram 2019). 
Additionally, e-commerce benefited poor people and small- and medium-sized businesses. Cloud Computing for EZ-Link provided timely information to more than 50,000 SMEs in Singapore. Lazada, Southeast Asia's number one online shopping destination created in 2012, now with Alibaba (its largest shareholder since 2016), provides services for more than 400,000 SMEs in Indonesia, Malaysia, Philippines, Singapore, Thailand, and Vietnam. Its business more than doubled in 2018 (Cadell and Aravindan 2018).

\subsection{Narrowing the digital gap and inequalities in countries in Africa and elsewhere}

Han (2018) estimates that levels of digitalisation of participating countries along the Belt and Road route increased by 2.78 per cent in 2016 compared to the previous year, while the average global growth rate was 2.1 per cent. Arguably, the better performance of the Belt and Road countries was attributed to the rapid construction of ICT network infrastructure and technical cooperation between China and the participating countries. As well as the previously mentioned case of Rwandan coffee farmers, Tanzania represents another example. China Telecom helped the country to install a fibre-optic transmission network. Huawei also signed a US $\$ 182 \mathrm{~m}$ deal for constructing landline and mobile ICT networks. Tanzania was upgraded from 'no internet application' to 'world-class' access, which has also resulted in the development of local ICTs and internet industries (TanzaniaInvest 2015).

Connectivity between business stakeholders and members of society by BRI member state users has also become more active. WeChat, including the payment system, was being adopted and adapted in other countries even before Tencent reached some of them. They are widespread for both business and personal use. They are used by small businesses and larger traders to settle transactions, including internationally. Their use has helped to establish relationships with suppliers and buyers and turned out to be particularly popular with people who trade agricultural products and natural resources (Oreglia 2019).

\subsection{Local capacity building}

As well as providing digital infrastructure, Chinese companies offered talent training to empower entrepreneurs and other users of digital technology. Alibaba offers training courses to future entrepreneurs from Africa and Southeast Asia and helps aspiring young entrepreneurs to develop businesses and innovations (Hsu 2018). Huawei established an overseas training centre in 2012 for global talents. By the end of March 2018, more than 40,000 technicians and experts had participated in the future seed programme at the centre. It also sets up research and development centres in Africa (Fu 2018).

\subsection{Protecting the environment}

The development of physical as well as digital infrastructure through the BRI has started to proceed economically in developing countries. However, China's own experience shows that economic prosperity can 
have negative environmental impact if there is little consideration for the environment. It is well known that many regions in China have suffered from serious environmental degradation, pollution, and urban heat island effects (Li 2013).

The BRI aspires to balance environmental and economic goals. The Digital Belt and Road (DBAR) programme was initiated in 2016 by Chinese scientists in cooperation with experts from 19 countries and seven international organisations. The aim was to improve environmental monitoring and data sharing, and to support policymaking. The Chinese Academy of Sciences (CAS) is investing more than 200m yuan (US\$32m) in the next five years to support the DBAR programme. According to the Chair of the programme:

Environmental and socio-economic information will be shared through a platform for big Earth data, scheduled for roll-out between 2016 and 2026. This open-access gateway will allow researchers, policymakers and the public to track changes, development and trends. The programme will investigate indices and indicators to feed into the UN's 2030 Sustainable Development Goals (Guo 2018).

\subsection{Institutional development}

According to $\mathrm{Xu}$ (2017), the Inspur Group has helped the digitalisation of the taxation administration of Zimbabwe. The engineers from the Inspur Group provided hands-on tutorials to the local technicians and engineers for four years. It did not charge the customers on a daily or even hourly rate. The success of the Inspur Group's work in Zimbabwe has attracted taxation bureaus from more than ten other African countries. In response, the Inspur Group has organised more than 500 overseas events about cloud computing and big data and has trained over 10,000 digitalisation professionals for Egypt, South Africa, and Vietnam.

\section{Discussion and conclusion}

A Chinese idiom may help to capture the role of the Digital Silk Road for the BRI: 'adding wings to a tiger' ( $r$ hu tian yi), which means to add more capacity to a strong force. As discussed, the Digital Silk Road has generated some benefits in the BRI countries, which contributes towards some of the SDGs. Its primary contribution would be to enhance connectivity and complement physical infrastructure. It helps to link some of the most disadvantaged or isolated countries or communities to the outside world and allow them to benefit directly from one of the world's markets through trade and entrepreneurship. It also empowers people and small businesses with information that they would not otherwise have had access to.

A growing number of developing countries in Africa, Southeast Asia, and the Middle East have become engaged with the Chinese government and Chinese companies on digital initiatives. The acceptance of this approach illustrates its potential value to these BRI countries. There are several advantages of the Digital Silk Road initiative, other than 
building large-scale physical infrastructure. For the companies and hosting governments, the costs of constructing digital infrastructure is much lower than for physical infrastructure projects. Although Chinese digital solutions and technologies may not be the most advanced, they meet the needs of developing countries and lower-income groups (Zhang 2017). Therefore, they have been particularly welcomed by lower-income countries and beneficial to the more impoverished populations, allowing them to benefit from international development.

Our review shows that the Digital Silk Road has not been able to offer direct solutions to environmental problems, despite efforts to collect the data. Data monitoring would help to generate future policies on evaluation and targeted environmental protection. However, data collection is not the same as delivering actual solutions. It will take a lot more commitment and supportive efforts to really deliver the goal to protect the environment. What digital data collection can achieve is that the increased availability of the digital network, information, and skills, the need for better environmental protection, and lower energy consumption can be better communicated to people around the world. This may play an essential role in pressing enterprises and consumers to change their behaviour in the future.

Another frequently raised issue is the need for bottom-up decisionmaking, voice channelling, and co-production. Despite the increased availability of these activities in the Chinese context, i.e. digital platforms, social media, and apps being more and more used for public consultation at the policy formation stage, these goals are not built into the BRI system (Seele, Jia and Helbing 2019). A more co-productive approach that involves not only the governments of the hosting countries of Chinese technologies, but also other stakeholders such as businesses, non-governmental organisations, and communities in these countries, may help to prevent some of the negative opinions or even resistance in the future, and thus enlist greater support for the sustainability of the BRI itself.

Digital technologies can be used for bad causes as well as good. Internationally, China has been portrayed negatively for trying to empower a surveillance state using technology. However, even if China refrains from using digital technologies to impose state control on its people, it cannot guarantee that other countries would do the same once they gain that same technological access. Therefore, as ICT networks increasingly operate across national boundaries and into some uncharted territories, there needs to be international cooperation to develop a legal framework to prevent ICT networks from being misused to cause problems at a more rapid pace.

A threat and possibly more of a reality than ever for the Digital Silk Road to contribute to the delivery of the SDGs, is the heated geopolitical contest between China and the US. Through punitive tariffs or business constraints, the new trading system built for poorer countries 
to boost international trade may be adversely affected. To what extent the improvement of development outcomes can be eroded as a result of this is still too early to tell, and more research should be done to develop a better understanding of the possible consequences. After all, delivering the SDGs and benefiting the poorest global populations would require world leaders to learn to take advantage of, rather than block, the new opportunities of digitally enabled development for the vast number of poor people.

\section{Notes}

* This IDS Bulletin is supported by the Center for International Knowledge on Development's (CIKD) China-UK Partnership Programme on Knowledge for Development.

+ The authors would like to thank Jing Gu and the two reviewers for their constructive comments on this article and Fei Teng from CIKD for helping to collect some of the data used in this article. Bingqin Li is funded by the UNSW SHARP Fund for her time devoted to this project.

1 Gong Sen, Executive Vice-President (Director-General) of the Center for International Knowledge on Development (CIKD) and Research Fellow of the Development Research Center of the State Council (DRC), China.

2 Li Bingqin is a SHARP Associate Professor and Director of the Chinese Social Policy programme at the Social Policy Research Centre, University of New South Wales (UNSW), Australia.

\section{References}

Adhikari, O. (2018) Sustainable Development and its Challenges in Developing Countries, Prague: International Young Nature Friends, www.iynf.org/2018/08/a-guide-to-sustainable-development-and-itschallenges-in-developing-countries/ (accessed 26 July 2019)

Agarwal, R.; Animesh, A. and Prasad, K. (2009) 'Social Interactions and the "Digital Divide": Explaining Variations in Internet Use', Information Systems Research 20.2: 159-316, https://doi.org/10.1287/isre.1080.0194 (accessed 26 July 2019)

Ahlfeldt, G.; Koutroumpis, P. and Valletti, T. (2014) Speed 2.0: Evaluating Access to Universal Digital Highways, CEIS Tor Vergata Research Paper Series 328, Rome: Centre for Economic and International Studies Ahmed, Z. (2018) 'Explaining the Unpredictability: A Social Capital Perspective on ICT Intervention', International fournal of Information Management 38.1: 175-86, https://doi.org/10.1016/j.ijinfomgt.2017.09.002 (accessed 26 July 2019)

Alexopoulos, K. (2018) 'Strengthening Connectivity of Countries in South and Central Asia, Particularly Landlocked and Least Developed Countries, to Link with Sub-Regional and Regional Transport and Trade Networks', presentation to Policy Dialogue, 7-8 September, Geneva: United Nations Economic Commission for Europe, www.unescap.org/sites/default/files/Konstantinos_\%20 Alexopoulos_7_8feb.pdf (accessed 13 October 2019) 
AliResearch (2019) Building the 21st Century Digital Silk Road - The Practice of Alibaba Economy, www.useit.com.cn/thread-23125-1-1.html (accessed 26 July 2019)

Almén, O. (2018) 'Participatory Innovations Under Authoritarianism: Accountability and Responsiveness in Hangzhou's Social Assessment of Government Performance', Journal of Contemporary China 27.110: 165-79, https://doi.org/10.1080/10670564.2018.1389003 (accessed 26 July 2019)

Arunmas, P. (2018) “"Taobao Village” Model Sought for Poor', Bangkok Post, 7 November, www.bangkokpost.com/thailand/ politics/1571226/taobao-village-model-sought-for-poor (accessed 26 July 2019)

Asian Scientist Neresroom (2017) 'NUS Teams Up with Alibaba Cloud and EZ-Link for Real-World Data Science', Asian Scientist, 24 January, www.asianscientist.com/2017/01/academia/alibaba-cloud-nusezlink-singapore/ (accessed 26 July 2019)

Asongu, S.A.; Le Roux, S. and Biekpe, N. (2018) 'Enhancing ICT for Environmental Sustainability in Sub-Saharan Africa', Technological Forecasting and Social Change 127: 209-16, https://doi.org/10.1016/j.techfore.2017.09.022 (accessed 26 July 2019)

Bai, Y.; Wang, W. and Zhang, L. (2018) 'How Long Do Returning Migrants Stay in their Home County: Evidence from Rural China during 1998 to 2015', paper presented at the International Association of Agricultural Economics Conference, Vancouver, 28 July-2 August, https://ageconsearch.umn.edu/record/277380 (accessed 26 July 2019)

Bonini, A. (2017) 'The Biggest Barriers to Universal Human Development', United Nations Development Programme Human Development Reports, http://hdr.undp.org/en/content/biggest-barriers-universalhuman-development (accessed 26 July 2019)

Cadell, C. and Aravindan, A. (2018) 'Alibaba Doubles Lazada Investment to $\$ 4$ billion in Aggressive Southeast Asian Expansion', Reuters, 19 March, www.reuters.com/article/us-alibaba-lazadafunding/alibaba-doubles-lazada-investment-to-4-billion-inaggressive-southeast-asian-expansion-idUSKBN1GV09W (accessed 16 August 2019)

CAEXPO Secretariat (2018) The China-ASEAN Information Harbor Forum on Cyber Culture Development Kicked Off Ceremoniously, Nanning: China-ASEAN Expo Secretariat, http://eng.caexpo.org/index. php? $\mathrm{m}=$ content $\& \mathrm{c}=$ index $\& \mathrm{a}=$ show $\&$ catid $=10106 \& \mathrm{id}=207479$ (accessed 26 July 2019)

Cao, J.H. (2016) 'On Connecting the "One Belt and One Road" Initiative to the 2030 Sustainable Development Agenda', International Outlook 8.3: 37-53

China Academy of Information and Communications Technology (CAICT) (2018) White Paper on China International Optical Cable Interconnection, Beijing: China Institute of Information and Communications Technology, www.caict.ac.cn/english/yjcg/ bps/201808/P020180829385778461678.pdf (accessed 26 July 2019) 
China News Agency (2017) 'China's Three Major Telecommunication Operators Help the "Information One Belt, One Road", 12 May, http://news.ifeng.com/a/20170512/51082867_0.shtml (accessed 26 July 2019)

Chinese Academy of Sciences (2017) Report on Remote Sensing Monitoring of China's Sustainable Development 2016, Beijing: Social Sciences Academic Press

Choi, C. and Yi, M.H. (2009) 'The Effect of the Internet on Economic Growth: Evidence from Cross-Country Panel Data', Economics Letters 105.1: 39-41, https://doi.org/10.1016/j.econlet.2009.03.028 (accessed 26 July 2019)

Chu, P.Y.; Yeh, S.C. and Chuang, M.C. (2008) 'Reengineering Municipality Citizen Electronic Complaint System through Citizen Relationship Management', Electronic Government, An International fournal 5.3: 288-309

Chu, Y. and Li, W. (2018) 'How to Push Through the "Digital SilkRoad", People's Tribune 13: 42-43

Ciampaglia, G.L. (2017) 'Fighting Fake News: A Role for Computational Social Science in the Fight Against Digital Misinformation', fournal of Computational Social Science 1.1: 147-53, https://doi.org/10.1007/s42001-017-0005-6 (accessed 26 July 2019)

Collier, P. (2007) The Bottom Billion: Why the Poorest Countries are Failing and What Can be Done About It, New York NY: Oxford University Press

Cyberspace Administration of China (2016) 'G20 Digital Economic Development and Cooperation Initiative', presented at the G20 Summit, Hangzhou, 5 September, www.g20.utoronto.ca/2016/160905-digital.html (accessed 26 July 2019)

Czernich, N.; Falck, O.; Kretschmer, T. and Woessmann, L. (2009) 'Broadband Infrastructure and Economic Growth', The Economic Fournal 121.552: 505-32, https://doi.org/10.1111/j.14680297.201 1.02420.x (accessed 26 July 2019)

de Melo, J. and Solleder, J-M. (2018) Barriers to Trade in Environmental Goods: How Important they are and What Should Developing Countries Expect from their Removal, CEPR Discussion Paper DP13320, London: Centre for Economic Policy Research, https://econpapers.repec.org/paper/ cprceprdp/13320.htm (accessed 26 July 2019)

Eastern Economic Corridor (2019) 'EEC-Alibaba Group Join Forces to Promote Thai Products', 26 July, www.eeco.or.th/en/pr/news/ press-release-eec-alibaba-group-join-forces-promote-thai-products (accessed 26 July 2019)

Fang, M.L.; Canham, S.L.; Battersby, L.; Sixsmith, J. and Sixsmith, A. (2018) 'Exploring Privilege in the Digital Divide: Implications for Theory, Policy, and Practice', The Gerontologist 59.1: e1-e15, https://doi.org/10.1093/geront/gny037 (accessed 26 July 2019)

Filho, W.L. et al. (2017) 'Identifying and Overcoming Obstacles to the Implementation of Sustainable Development at Universities', fournal of Integrative Environmental Sciences 14.1: 93-108, https://doi.org/10.1080/1943815X.2017.1362007 (accessed 26 July 2019) 
Fu, Z.G. (2018) 'Digital Silk-Road: New Bond between China and Southeast Asia', Guangming Daily, 12 May

Gahigi, M.A. (2019) 'Rwandan Coffee Excites Buyers on Alibaba Platform', Rwanda Today, 2 January, http://rwandatoday.africa/ news/Rwandan-coffee-excites-buyers-on-Alibaba-platform/43832144918764-xtdxx0/index.html (accessed 26 July 2019)

Gao, J. (2015) 'Performance Measurement and Management in the Public Sector: Some Lessons from Research Evidence', Public Administration and Development 35.2: 86-96, https://doi.org/10.1002/pad.1704 (accessed 26 July 2019)

Giroux, H.A. (2014) 'Totalitarian Paranoia in the Post-Orwellian Surveillance State', Cultural Studies 29.2: 108-40, https://doi.org/10.1080/09502386.2014.917118 (accessed 26 July 2019)

Goggin, G.; Yu, H.; Fisher, K.R. and Li, B. (2019) 'Disability, Technology Innovation and Social Development in China and Australia', fournal of Asian Public Policy 12.1: 34-50, https://doi.org/10.1080/17516234. 2018.1492067 (accessed 26 July 2019)

Gong, S.; Gu, J. and Teng, F. (2019) The Impact of the Belt and Road Initiative Investment in Digital Connectivity and Information and Communication Technologies on Achieving the SDGs, K4D Emerging Issues Report, Brighton: IDS, https://opendocs.ids.ac.uk/opendocs/ handle/123456789/14395 (accessed 16 August 2019)

Gu, J. and Carey, R. (2019) 'China's Development Finance and African Infrastructure Development', in Arkebe Oqubay and Justin Yifu Lin (eds), China-Africa and an Economic Transformation, Oxford: Oxford University Press

Guo, H. (2018) 'Steps to the Digital Silk Road', Nature 554.7690: 25-27, doi:10.1038/d41586-018-01303-y (accessed 26 July 2019)

Guterres, A. (2017) 'Remarks at the Opening of the Belt and Road Forum', United Nations Secretary-General, 14 May, www.un.org/sg/en/content/sg/speeches/2017-05-14/secretarygeneral $\% \mathrm{E} 2 \% 80 \% 99$ s-belt-and-road-forum-remarks (accessed 26 July 2019)

Han, Y. (2018) 'Impacts of Digital Divide on Trade between China and Participating Countries along the Belt and Road Route', Master's dissertation, Beijing University of Posts and Telecommunications

Hao, C.J. (2019) 'China's Digital Silk Road: A Game Changer for Asian Economies', The Diplomat, 30 April, https://thediplomat.com/2019/04/chinas-digital-silk-road-a-gamechanger-for-asian-economies/ (accessed 26 July 2019)

He, X. (2019) 'Digital Entrepreneurship Solution to Rural Poverty: Theory, Practice and Policy Implications', Fournal of Developmental Entrepreneurship 24.1: 1950004, https://doi.org/10.1142/S1084946719500043 (accessed 26 July 2019)

Hong, Y.A.; Zi, Z.; Fang, Y. and Shi, L. (2017) 'The Digital Divide and Health Disparities in China: Evidence from a National Survey and Policy Implications', fournal of Medical Internet Research 19.9: e317, https://doi.org/10.2196/jmir.7786 (accessed 11 September 2019) 
Houlihan, B.; Tan, T-C. and Green, M. (2010) 'Policy Transfer and Learning from the West: Elite Basketball Development in the People's Republic of China', Fournal of Sport and Social Issues 34.1: 4-28, https://doi.org/10.1177/0193723509358971 (accessed 26 July 2019)

Hsu, J.W. (2018) 'Alibaba Helps to Shape Malaysia's E-Commerce Future', Alizia, 26 January, www.alizila.com/alibaba-helps-toshape-malaysia-e-commerce-future/?spm=a2738.11138611. jbrkevgy.3.27dd39de3xDbbV (accessed 26 July 2019)

Hwang, E.; Guo, X.; Tan, Y. and Dang, Y. (2018) 'Mobilizing Healthcare across Geography through Telemedicine Consultations', ICIS 2018 conference proceedings, http://misrc.umn.edu/workshops/2018/fall/Paper_Elina\%20 Hwang.pdf (accessed 26 July 2019)

Inspur Group (2017) Inspur Launches the 'BE'R' Digital Economy Strategic Alliance, 2 November, www.prnewswire.com/news-releases/inspurlaunches-the-br-digital-economy-strategic-alliance-300548285.html (accessed 26 July 2019)

iResearch (2018) A Comprehensive Report of Chinese Mobile Internet Businesses Abroad in 2018, http://report.iresearch.cn/wx/report.aspx?id=3194 (accessed 26 July 2019)

James, J. (2009) 'From the Relative to the Absolute Digital Divide in Developing Countries', Technological Forecasting and Social Change 76.8: 1124-1129, https://doi.org/10.1016/j.techfore.2009.01.004 (accessed 26 July 2019)

Jin, L. (2018) 'Synergies between the Belt and Road Initiative and the 2030 SDGs: From the Perspective of Development', Economic and Political Studies 6.3: 278-92, https://doi.org/10.1080/20954816.2018.1498990 (accessed 26 July 2019)

Katz, B. and Jones, A.C. (2015) 'Beneath China's GDP Slowing Down', Brookings, 31 March, www.brookings.edu/blog/theavenue/2015/03/31/beneath-chinas-gdp-slowdown/ (accessed 26 July 2019)

Leong, G.M.L.; Pan, S.L.; Newell, S. and Cui, L. (2016) 'The Emergence of Self-Organizing E-Commerce Ecosystems in Remote Villages of China: A Tale of Digital Empowerment for Rural Development', Mis Quarterly 40.2: 475-84

Li, B. (2018) 'Top-Down Place-Based Competition and Award: Local Government Incentives for Non-GDP Improvement in China', fournal of Chinese Governance 3.4: 397-418, https://doi.org/10.1080/23812346.2018.1516418 (accessed 26 July 2019)

Li, B. (2017) 'Inequalities and Social Policies in China', Plenary Speech, Australian Social Policy Conference, University of New South Wales, Sydney, 26 September

Li, B. (2013) 'Governing Urban Climate Change Adaptation in China', Environment and Urbanization 25.2: 413-27, https://doi.org/10.1177/0956247813490907 (accessed 26 July 2019) 
Li, L.; Du, K.; Zhang, W. and Mao, J.Y. (2018) 'Poverty Alleviation Through Government-Led E-Commerce Development in Rural China: An Activity Theory Perspective', Information Systems fournal 29.4: 914-52, https://doi.org/10.1111/isj.12199 (accessed 26 July 2019)

Liu, S.L. and Hu, A.G. (2010) 'Transport Infrastructure and Economic Growth: Perspective from China's Regional Disparities', China Industrial Economics 4: 14-23, http://gb.oversea.cnki.net/kcms/detail/detail.aspx?dbCode=cjfd\&Query $\mathrm{ID}=14 \&$ CurRec $=2 \&$ filename $=$ GGYY201004003\&dbname $=$ CJFD 2010 (accessed 13 October 2019)

Maurer, B.; Nelms, T.C. and Rea, S.C. (2018) " "Bridges to Cash": Channelling Agency in Mobile Money', in J.A. Bell and J.C. Kuipers (eds), Linguistic and Material Intimacies of Cell Phones, Abingdon: Routledge

Mbise, T.; Taal, S.; Roberts, M. and Lammersen, F. (2018) Digital Connectivity and E-Commerce: Overview of Financing Flows and Examples of Aid for Trade Support, Staff Working Paper ERSD-2018-08, Geneva: World Trade Organization

Mcdonald, M. et al. (2002) 'Environmental Protection Agency's Environmental Monitoring and Assessment Program (EMAP) in the 21st Century', American Institute of Hydrology 18.1-4: 133-43, https://cfpub.epa.gov/si/si_public_record_report. cfm?Lab=NHEERL\&dirEntryId=115285 (accessed 13 October 2019)

McNally, G.A. (2004) 'Sichuan: Driving Capitalist Development Westward', China Quarterly 178: 426-47, https://doi.org/10.1017/S0305741004000244 (accessed 26 July 2019)

Mills, K.L. (2016) 'Possible Effects of Internet Use on Cognitive Development in Adolescence', Media and Communication 4.3: 4-12, http://dx.doi.org/10.17645/mac.v4i3.516 (accessed 26 July 2019)

Mohabir, N.; Jiang, Y. and Ma, R. (2017) 'Chinese Floating Migrants: Rural-Urban Migrant Labourers' Intentions to Stay or Return', Habitat International 60: 101-10, https://doi.org/10.1016/j.habitatint.2016.12.008 (accessed 26 July 2019)

Mugisha, I.R. (2018) 'Alibaba, Rwanda Launch Electronic Trade Platform', The EastAfrican, 3 November, www.theeastafrican.co.ke/business/Alibaba-Rwanda-launchelectronic-trade-platform/2560-4835510-9stilcz/index.html (accessed 26 July 2019)

Murendo, C.; Wollni, M.; De Brauw, A. and Mugabi, N. (2018) 'Social Network Effects on Mobile Money Adoption in Uganda', Fournal of Development Studies 54.2: 327-42, https://doi.org/10.1080/00220388. 2017.1296569 (accessed 26 July 2019)

Ng, E. and Tan, B. (2018) 'Achieving State-of-the-Art ICT Connectivity in Developing Countries: The Azerbaijan Model of Technology Leapfrogging', Electronic Fournal of Information Systems in Developing Countries 84.3: e12027, https://doi.org/10.1002/isd2.12027 (accessed 26 July 2019) 
Ngar-Yin Mah, D. and Hills, P.R. (2014) 'Policy Learning and CentralLocal Relations: A Case Study of the Pricing Policies for Wind Energy in China (from 1994 to 2009)', Environmental Policy and Governance 24.3: 216-32, https://doi.org/10.1002/eet.1639 (accessed 26 July 2019)

Office of the Leading Group for the BRI (2019) 'Building a "Belt and Road Initiative": Progress, Contribution and Prospects', Xinhua News, 22 April, www.xinhuanet.com/world/201904/22/c_1124400071.htm (accessed 29 July 2019)

Olsen, S.H. et al. (2014) 'Implementing the Sustainable Development Goals (SDGs): An Assessment of the Means of Implementation (MOI)', Institute for Global Environmental Strategies Draft ISAP Conference Paper, 24 July, www.files.ethz.ch/isn/183571/ISAP2014_ SDGs_conference_paper-final.pdf (accessed 26 July 2019)

Onitsuka, K.; Hidayat, A.R.; Rohman, T. and Huang, W. (2018) 'Challenges for the Next Level of Digital Divide in Rural Indonesian Communities', Electronic Journal of Information Systems in Developing Countries 84.2: e12021, https://doi.org/10.1002/isd2.12021 (accessed 26 July 2019)

Oreglia, E. (2019) 'Chinese Digital Ecosystems Go Global: Myanmar and the Diffusion of Chinese Smartphones', Hong Kong Free Press, 27 January, www.hongkongfp.com/2019/01/27/chinese-digitalecosystems-go-global-myanmar-diffusion-chinese-smartphones/ (accessed 26 July 2019)

Renwick, N. (forthcoming, 2019) 'The Belt and Road Initiative: Infrastructure and Sustainable Development', in Sustainable Economy and Emerging Markets, London: Routledge

Renwick, N.; Gu, J. and Gong, S. (2018) The Impact of Belt and Road Initiative (BRI) Investment in Infrastructure on Achieving the Sustainable Development Goals, K4D Emerging Issues Report, Brighton: IDS, https://opendocs.ids.ac.uk/opendocs/handle/123456789/14097 (accessed 26 July 2019)

Riley, E. (2018) 'Mobile Money and Risk Sharing Against Village Shocks', Fournal of Development Economics 135: 43-58, https://doi.org/10.1016/j.jdeveco.2018.06.015 (accessed 26 July 2019)

Seele, P; Jia, C.D. and Helbing, D. (2019) 'The New Silk Road and its Potential for Sustainable Development: How Open Digital Participation Could Make BRI a Role Model for Sustainable Businesses and Markets', Asian Journal of Sustainability and Social Responsibility 4.1: 1-7, https://doi.org/10.1186/s41180-018-0021-3 (accessed 26 July 2019)

Sen, A. (2004) 'Capabilities, Lists, and Public Reason: Continuing the Conversation', Feminist Economics 10.3: 77-80, https://doi.org/10.1080/1354570042000315163 (accessed 26 July 2019)

Shiel, C.; Smith, N. and Cantarello, E. (2018) 'Aligning Campus Strategy with the SDGs: An Institutional Case Study', in W.L. Filho et al. (eds), Universities as Living Labs for Sustainable Development, Switzerland: Springer Nature, https://doi.org/10.1007/978-3-030-15604-6 (accessed 26 July 2019) 
Sriram, M. (2019) Alibaba Re-Evaluates India Strategy, May Focus on Smaller Deals', livemint, 6 May, www.livemint.com/companies/news/ alibaba-looks-to-focus-on-small-deals-in-india-1557082 189868.html (accessed 26 July 2019)

Stewart, A. (2019) 'The Online Silk Road: China's Growing Influence on Tech in the UAE', The National, 4 February, www.thenational.ae/ arts-culture/the-online-silk-road-china-s-growing-influence-on-techin-the-uae-1.821809 (accessed 26 July 2019)

Tan, Y.; Yang, Y.; Leng, B. and Li, T. (2011) 'Urban Network System in the Chengdu-Chongqing Region in the Perspective of Advanced Producer Service', Progress in Geography 30.6: 724-32, doi:10.11820/dlkxjz.2011.06.010 (accessed 12 September 2019)

TanzaniaInvest (2015) Tanzanian and Chinese Telecom Companies Sign USD 182 Million Deal to Build Landline and Mobile Networks, 30 January, www.tanzaniainvest.com/telecoms/tanzania-telecommunicationslimited-huawei-technologies-sign-usd-182-million-deal (accessed 26 July 2019)

Thapa, D. and Sein, M.K. (2018) 'An Ecological Model of Bridging the Digital Divide in Education: A Case Study of OLPC Deployment in Nepal', Electronic Journal of Information Systems in Developing Countries 84.2: e12018, https://doi.org/10.1002/isd2.12018 (accessed 26 July 2019)

Trojanow, I.; Zeh, J.; Alvizu, J. and Petersdorff, M. (2015) 'Attack on Freedom: The Surveillance State, Security Obsession, and the Dismantling of Civil Rights', German Studies Review 38.2: 271-84, https://doi.org/10.1353/gsr.2015.0065 (accessed 12 September 2019)

Tu, J.; Wang, C. and Wu, S. (2018) 'Using Technological Innovation to Improve Health Care Utilization in China's Hospitals: The Emerging "Online" Health Service Delivery', fournal of Asian Public Policy 11.3: 316-33, https://doi.org/10.1080/17516234.2017.1396953 (accessed 26 July 2019)

Turvey, G.G. and Xiong, X. (2017) 'Financial Inclusion, Financial Education, and E-Commerce in Rural China', Agribusiness 33.2: 279-85, https://doi.org/10.1002/agr.21503 (accessed 26 July 2019)

Urmee, T. and Md, A. (2016) 'Social, Cultural and Political Dimensions of Off-Grid Renewable Energy Programs in Developing Countries', Renewable Energy 93: 159-67, https://doi.org/10.1016/j.renene.2016.02.040 (accessed 26 July 2019)

Viney, S.; Pan, N. and Fang, J. (2017) 'One Belt, One Road: China Heralds "Digital Silk Road"; Foresees Internet-Era Power Shift Soon', ABCNews, 5 December, www.abc.net.au/news/2017-12-05/chinapresents-foundations-of-digital-silk-road-at-internet-meet/9223710 (accessed 26 July 2019)

World Bank (2018) Belt and Road Initiative, 29 March, www.worldbank.org/en/topic/regional-integration/brief/belt-androad-initiative (accessed 26 July 2019)

Xiang, K. (2017) 'Essence, Structure, and Path to Construction of Digital Silk-Road from the Perspective of Digital Economy', West Forum 27.6: 11-16 
Xinhua News (2017) 'Huawei Establishes Open Lab in Bangkok to Help Digital Transformation in Thailand', 2 June, http://news.xinhuanet.com/world/2017-06/02/c_1121072400.htm (accessed 26 July 2019)

Xu, H. (2017) 'A Golden Time From BRI for the Inspur Group', CCTV News, 14 April, http://news.cctv.com/2017/04/14/

ARTIurqIyISWveaT8lYkYHnb170414.shtml (accessed 29 July 2019)

Xue, L. and Weng, L.F. (2018) 'Thoughts on China's Belt and Road Initiative for Promoting UN 2030 Sustainable Development Goals', Bulletin of Chinese Academy of Sciences 33.1: 40-47, www.bulletin.cas.cn/publish_article/2018/1/20180107.htm (accessed 13 October 2019)

Yang, H.H.; Zhu, S. and MacLeod, J. (2018) 'Promoting Education Equity in Rural and Underdeveloped Areas: Cases on ComputerSupported Collaborative Teaching in China', EURASIA fournal of Mathematics, Science and Technology Education 14.6: 2393-2405, https://doi.org/10.29333/ejmste/89841 (accessed 26 July 2019)

Yu, B.; Ndumu, A.; Mon, L.M. and Fan, Z. (2018) 'E-Inclusion or Digital Divide: An Integrated Model of Digital Inequality', fournal of Documentation 74.3: 552-74, https://doi.org/10.1108/JD-10-2017-0148 (accessed 26 July 2019)

Zhang, L.; Mol, A.P. and He, G. (2016) 'Transparency and Information Disclosure in China's Environmental Governance', Current Opinion in Environmental Sustainability 18: 17-24, https://doi.org/10.1016/j.cosust.2015.03.009 (accessed 26 July 2019)

Zhang, Y.S. (2017) Development of Huawei Heavily Depended on the Belt and Road, http://finance.sina.com.cn/meeting/2017-11-30/docifyphxwa7115289.shtml (accessed 26 July 2019)

Zhong, X. (2018) 'Information Technologies, Policy Leverage, and the Entrepreneurial Spirit: Building Cross-Sectoral Collaboration for Disability Employment in China', Journal of Asian Public Policy 2018: 1-19, https://doi.org/10.1080/17516234.2018.1511220 (accessed 26 July 2019) 
